\title{
STUDIES ON THE EFFECTS OF ALCOHOL, NICOTINE AND CAFFEINE ON WHITE MICE \\ II. EFFECTS ON ACTIVITY
}

L. B. NICE

From the Laboratory of Physiology in the Harvard Medical School

THREE FIGURES

\section{CONTENTS}

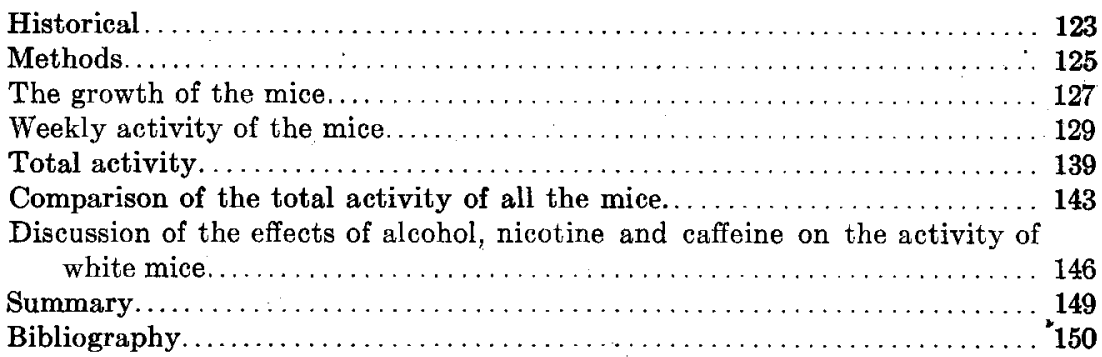

\section{HISTORICAL}

During the past twenty years the effects of drugs on the activity of men and animals have been studied by many investigators. With but few exceptions however, these studies have extended over short periods of time and the drugs have been given intermittently.

\section{Alcohol}

Hodge ('03) compared the spontaneous exercise of a pair of alcoholic and a pair of control dogs and found that the alcoholic female exercised 57 per cent as much as the control female and the alcoholic male 71 per cent as much as the control male. Their activity was measured by means of pedometers in their collars. 
Stewart ('98) gave two grey rats 20 per cent alcohol to drink. The activity of the alcoholic rats, as measured by revolving cages, surpassed that of the controls. - Thirty per cent alcohol decreased the activity of white rats.

In investigations on men Lombard ('92), Frey ('96), Kraepelin ('99), Rossi ('94) and Schumburg ('99) showed that small doses of alcohol increased the amount of work done with the ergograph. Schnyder ('03) observed that alcohol when taken in a fasting condition, increased the amount of work done with the ergograph but when taken after or during a meal decreased it. With Hellsten ('04) 80 grams of absolute alcohol diminished the amount of work he could perform. These doses were so large, however, that they produced disturbances of digestion. Aschaffenburg ('96) found that wine decreased the efficiency of typesetters. Rivers ('08) considers that the increase of work noted by the above investigators under the influence of alcohol was due to faulty methods. The interest of taking the alcohol stimulated the subjects to extra exertions. His own experiments were carried on with control mixtures so the subjects did not know when they were taking alcohol. He states that "small doses, varying from 5 to $20 \mathrm{cc}$. of absolute alcohol have no effect on the amount or nature of the work performed with the ergograph, either immediately or within several hours of their administration."

\section{Nicotine}

So far as I can find, no experiments have been made on testing the effects of nicotine on muscular activity. Tobacco was found by Lombard ('92), Harley ('94), Féré ('04) and Rivers ('08) to decrease the amount of muscular work as recorded by the ergograph, although the pleasurable sensations connected with smoking would be expected to stimulate the subject and thus increase the amount of work done.

The fact that tobacco is forbidden to athletes when in training for tests that require great muscular strength shows that it is generally considered to have a depressing effect on muscular activity. 


\section{Caffeine}

Caffeine was shown by Mosso ('93), Koch ('94), Hoch and Kraepelin ('96), Schumburg ('99) and Rivers ('08) to increase the capacity for work with the ergograph. From the results of these experiments Rivers ('08) says:

This stimulating action persists for a considerable time after the substance has been taken without there being any evidence, with moderate doses, of reaction leading to a diminished capacity for work, the substance thus really diminishing and not merely obscuring the effects of fatigue. When taken in excess the stimulating action may be so transitory, and followed by so great a decrease that it may legitimately be spoken of as an accelerator of fatigue.

\section{METHODS}

This study was undertaken to find the effects of alcohol, nicotine and caffeine on the spontaneous activity of white mice when kept under the influence of these drugs in moderate quantities all the time.

Sixteen male mice eight weeks old were used in the experiment. They were all descendents of one pair of mice whose offspring had been inbred for four generations. These mice belonged to the fourth generation and came from four different lots, each lot being the young of one male and several females. One mouse from each lot was placed in each of the experimental lines. Thus mice of the same sex, the same age, and very closely related were the subjects of this investigation.

Four lines were carried: one was given alcohol, a second nicotine, a third caffeine and a fourth was carried for controls. The alcohol and nicotine were given in the same proportions as in preceding experiments, as on these strengths the mice seemed to keep in good health. The caffeine was given in a 1:300 solution.

Each mouse in the alcohol line was given 35 per cent alcohol to drink instead of water, and every other day, 3 cc. of 35 per cent alcohol was added to its crackers and milk.

Each mouse in the nicotine line received 1:1000 nicotine sulphate solution to drink instead of water, and had $3 \mathrm{cc}$. of 1:1000 nicotine sulphate added to its crackers and milk every other day. 
In the caffeine line each mouse drank 1:300 caffeine citrate solution instead of water, and every other day 3 cc. of 1:300 caffeine solution was added to the crackers and milk.

All of the sixteen mice were given the same food which consisted of buckwheat and oats, every other day crackers and milk, and once or twice a week meat.

The experiment continued from November 18 to June 8. During the winter months the room was heated with hot water and remained at about $65^{\circ} \mathrm{F}$.

To study the spontaneous activity of these mice revolving cages were devised. These cages are similar to those used by Stewart ('98) and later by Slonaker ('07, '12) in their studies on rats. The cages are 6 inches wide by 10 inches in diameter, and made of 8-mesh galvanized wire. Each cage is fastened to an axle which revolves with the cage. The axle is $\frac{1}{4}$ inch in diameter and 18 inches long. The ends of the axle are pointed and set into the end of a bored out set screw forming a pinion which by reducing friction permits the cages to revolve very easily. By means of turning the set screw the pinions can be adjusted in case of wear. The cages are mounted as shown in the accompanying photograph (fig. 1).

The revolutions of each cage are recorded by means of an alarm clock whose balance wheel had been removed. A wire about 6 inches long is attached to the escapement lever of the clock and to one end of a wooden lever which rests on the axle near one end of a cage. In one brass hub of each cage two pins are set on opposite sides of the axle, and $1 \frac{1}{2}$ inches from it. These pins are parallel with the axle. As a cage revolves the end of the wooden lever is raised by each pin in turn causing the clock to register. Each revolution of a cage corresponds to one second on the clock.

Each cage is supplied with a nest box made of galvanized tin $2 \frac{3}{4}$ inches wide, $2 \frac{3}{4}$.inches long and 2 inches deep. These are swung to the axle by two wire hooks attached to the top of the nest box near its ends. A tunnel $1 \frac{1}{8}$ inches square having a wire mesh floor leads to the opening in one end of the nest box where the mouse enters. The floor of the nest box is a hinged door. 
On the top of the nest box is a feed box 3 inches long and 1 inch wide with two compartments, one for grain, the other for crackers and milk. The feed box is held in place by a spring clip. Another clip holds a small wide mouthed bottle which is inverted. This bottle contains the water or drug which the mouse drinks. In the mouth of this bottle is a rubber stopper with an opening through it $\frac{1}{2}$ inch in diameter. Through this opening a glass tube

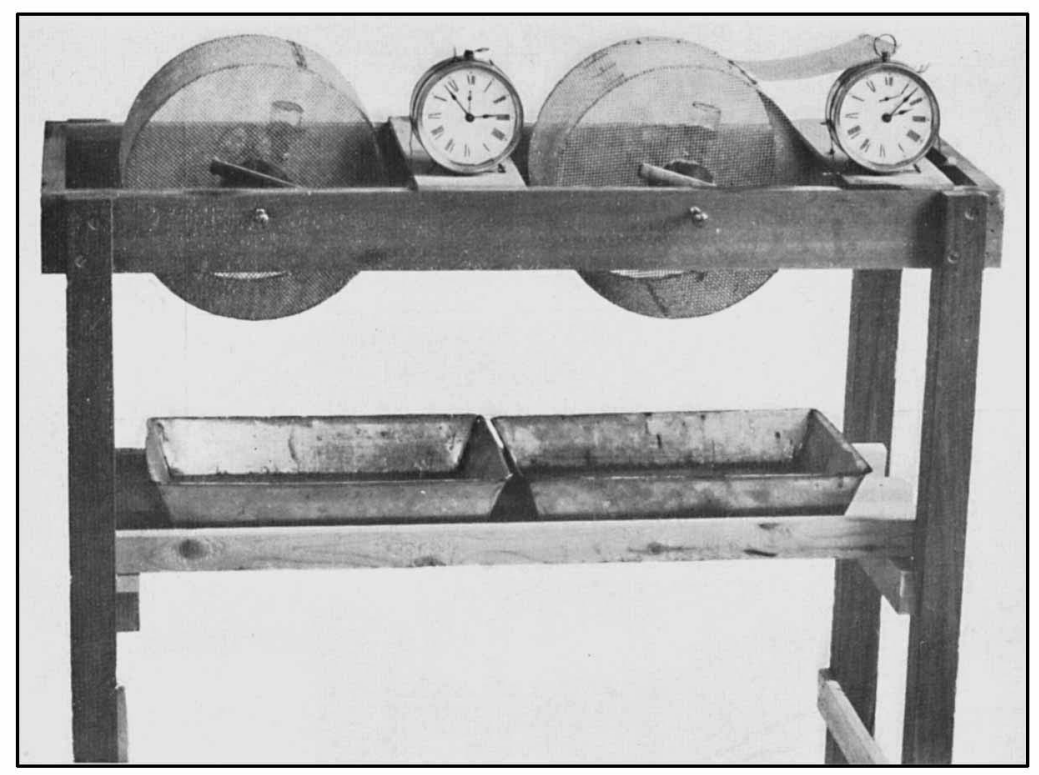

Fig. 1 Revolving cages and recording clocks

$\frac{3}{8}$ inch in diameter inside is inserted. The lower end of the glass tube is drawn towards a point making an opening $\frac{1}{4}$ inch in diameter. This device compelled all the mice to drink directly from the bottles.

THE GROWTH OF THE MICE

The mice were weighed at the beginning of the experiment when they were eight weeks old. They were weighed once a week during the next two months and once each month the next five months. 


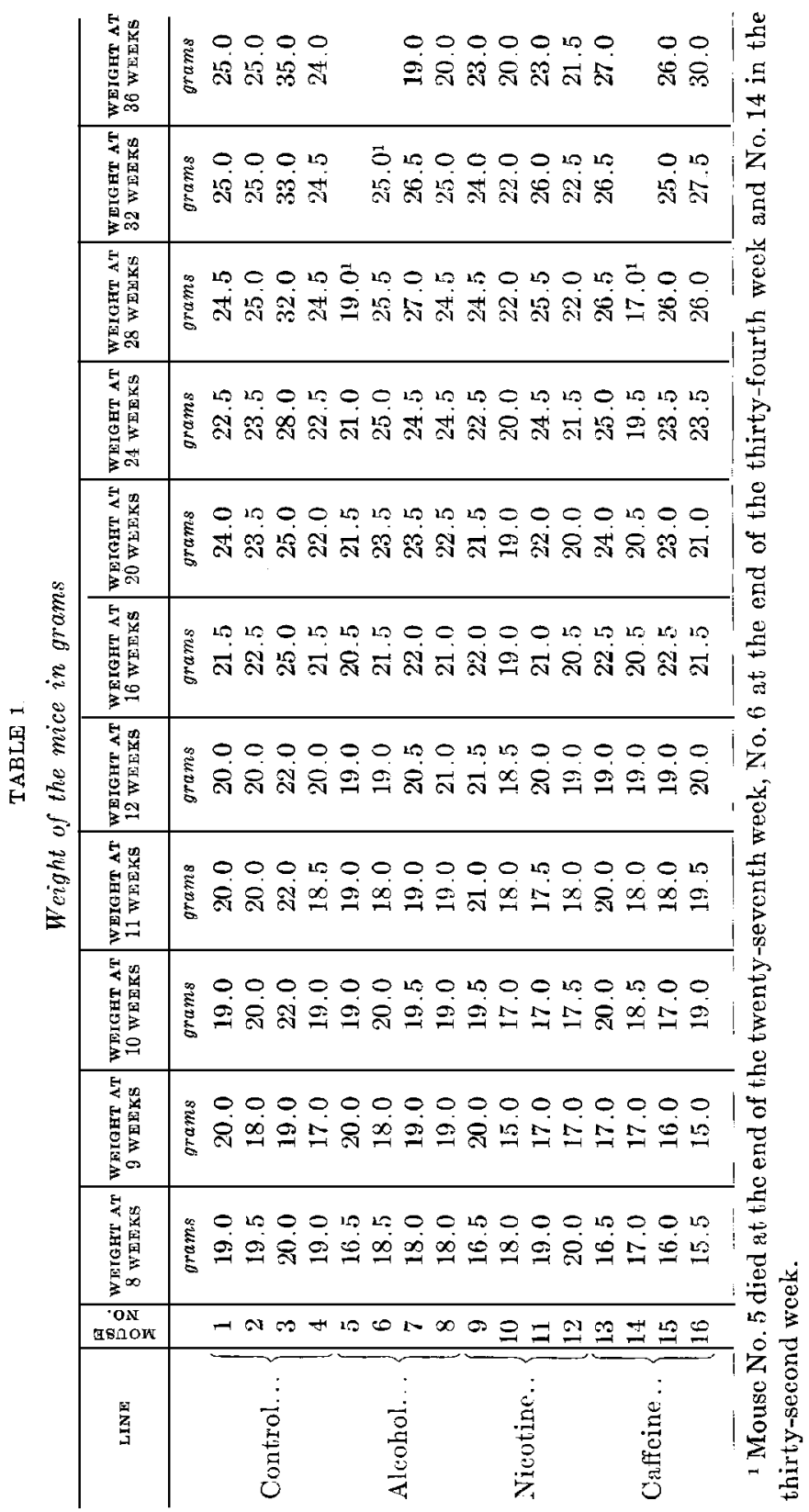


At eight weeks the control mice averaged 19.5 grams in weight, the alcohol mice 18 grams, the nicotine mice 18.5 grams and the caffeine mice 16 grams. At twenty-four weeks the control mice averaged 24 grams, the alcohol mice 24 grams, the nicotine mice 22 grams and the caffeine mice 23 grams. At thirty-six weeks the control mice averaged 27.3 grams, the alcohol mice 19.5 grams, the nicotine mice 22 grams and the caffeine mice 27.6 grams.

The control mice gained 4.5 grams each in the first sixteen weeks of the experiment and 3.3 grams in the last twelve weeks. The alcohol mice had gained 6 grams each when twenty-four weeks old, but had lost 4.5 grams on an average at the end of the experiment. The nicotine mice gained 3.5 grams each by the twenty-fourth week, and had gained no more at the end of the experiment. The caffeine mice gained the most of all, 7 grams in the first sixteen weeks and 4.6 grams in the last twelve weeks.

The average gain for the alcohol mice was 1.5 grams, for the nicotine mice 3.5 grams, for the control mice 7.8 grams and for the caffeine mice 11.6 grams.

\section{WEEKLY ACTIVITY OF THE MICE}

The number of revolutions registered by each clock was recorded at 12.30 P.M. every day. In the following tables the number of revolutions that each mouse ran are recorded by weeks.

Mouse No. 1 exhibited its greatest activity from the tenth to the eighteenth week, then became somewhat less active, increased again at the twenty-fifth week and then decreased rather gradually till the end of the experiment. Its maximum run was 139078 revolutions at the thirteenth week and its minimum run was 48380 revolutions at the thirty-fourth week. Its average run per week was 92004 revolutions.

No. 2 exhibited its greatest activity from the eleventh to the seventeenth week and then had a second period of high activity from the twenty-fifth to the twenty-ninth week. Its maximum run was 147576 revolutions at the fourteenth week and its minimum run was 59320 revolutions at the thirty-fifth week. Its average run per week was 95622 revolutions. 
TABLE 2

Number of revolutions per week of the mice in the control line

\begin{tabular}{|c|c|c|c|c|}
\hline $\begin{array}{l}\text { AGE OF MICW IN } \\
\text { WEEKS }\end{array}$ & $\begin{array}{c}\text { Mouse } \\
\text { No. } 1\end{array}$ & $\begin{array}{l}\text { MOEBE } \\
\text { No. } 2\end{array}$ & $\begin{array}{l}\text { моणgू } \\
\text { No. } 3\end{array}$ & $\begin{array}{l}\text { Moves } \\
\text { No. } 4\end{array}$ \\
\hline 9 & 80243 & 78785 & 55718 & 63878 \\
\hline 10 & 120935 & 82528 & 71041 & 123370 \\
\hline 11 & 122119 & 118306 & 99070 & 139978 \\
\hline 12 & 132593 & 125001 & 100003 & 120495 \\
\hline 13 & 139078 & 140830 & 81004 & 101626 \\
\hline 14 & 126355 & 147576 & 98966 & 80772 \\
\hline 15 & 123957 & 131274 & 81620 & 84200 \\
\hline 16 & 94870 & 129195 & 80028 & 94145 \\
\hline 17 & 92598 & 119668 & 85370 & 109275 \\
\hline 18 & 108405 & 91304 & 69584 & 129304 \\
\hline 19 & 86990 & 84900 & 73100 & 144913 \\
\hline 20 & 66117 & 83987 & 78744 & 105902 \\
\hline 21 & 74287 & 85647 & 58647 & 135,978 \\
\hline 22 & 72890 & 64281 & 58119 & 130395 \\
\hline 23 & 82120 & 85955 & 76740 & 125572 \\
\hline 24 & 88454 & 93540 & 54545 & 68147 \\
\hline 25 & 107148 & 109515 & 54532 & 126018 \\
\hline 26 & 91722 & 101215 & 60060 & 116095 \\
\hline 27 & 93892 & 74380 & 54104 & 105780 \\
\hline 28 & 88755 & 110640 & 55180 & 100500 \\
\hline 29 & 67071 & 119481 & 41058 & 78013 \\
\hline 30 & 77439 & 63365 & 40881 & 84547 \\
\hline 31 & 88028 & 81600 & 47324 & 94140 \\
\hline 32 & 85345 & 85102 & 52164 & 105615 \\
\hline 33 & 72652 & 74825 & 36155 & 91057 \\
\hline 34 & 48380 & 72453 & 39825 & 77830 \\
\hline 35 & 74460 & 59320 & 40746 & 62100 \\
\hline 36 & 69195 & 63554 & 41247 & 57633 \\
\hline Average. & 92004 & 95622 & 63770 & 102045 \\
\hline
\end{tabular}

No. 3 was the least active of all the controls. It reached its maximum of 100003 at the twelfth week and decreased steadily to the end of the experiment. Its minimum run was 36155 revolutions at the thirty-third week. Its average weekly run was 63770 revolutions.

No. 4 was the most active of the control mice. It showed high activity from the tenth to the thirteenth week, from the seventeenth to the twenty-third week, from the twenty-fifth to the twenty-eighth week and finally at the thirty-second week. Its 
maximum run was 144913 revolutions at the nineteenth week and its minimum run was 57633 revolutions at the thirty-sixth week. Its average run per week was 102045 revolutions.

Mouse No. 5 ran its maximum amount of 125301 revolutions during the eleventh week and decreased rather rapidly till the twenty-seventh week when it died. Its minimum run was 2464 revolutions the twenty-sixth week. Its average run per week was 57615 revolutions.

TABLE 3

Number of revolutions per week of the mice in the alcohol line

\begin{tabular}{|c|c|c|c|c|}
\hline $\begin{array}{l}\text { AGE OF MICE IN } \\
\text { WEEKS }\end{array}$ & $\begin{array}{l}\text { Mov8E } \\
\text { No. } 5\end{array}$ & $\begin{array}{l}\text { MOUsE } \\
\text { No. } 6\end{array}$ & $\begin{array}{l}\text { Mouse } \\
\text { No. } 7\end{array}$ & $\begin{array}{l}\text { MOUSEI } \\
\text { No. } 8\end{array}$ \\
\hline 9 & 57634 & 41370 & 28430 & 45395 \\
\hline 10 & 74915 & 81694 & 76230 & 122193 \\
\hline 11 & 125301 & 58444 & 132113 & 131473 \\
\hline 12 & 56542 & 15404 & 96680 & 93965 \\
\hline 13 & 104745 & 31693 & 142762 & 61901 \\
\hline 14 & 34380 & 32522 & 128495 & 83629 \\
\hline 15 & 80092 & 63128 & 129393 & 86196 \\
\hline 16 & 69722 & 79258 & 113,560 & 83327 \\
\hline 17 & 74074 & 86895 & 117005 & 83658 \\
\hline 18 & 56969 & 69616 & 99138 & 72748 \\
\hline 19 & 52830 & 71204 & 96925 & 68684 \\
\hline 20 & 57087 & 57318 & 112247 & 81660 \\
\hline 21 & 51785 & .54427 & 97093 & 61738 \\
\hline 22 & 47297 & 63423 & 89195 & 69655 \\
\hline 23 & 45628 & 66502 & 96835 & 77245 \\
\hline 24 & 43680 & 71510 & 76733 & 67364 \\
\hline 25 & 56831 & 75558 & 97210 & 67607 \\
\hline 26 & 2464 & 54630 & 85420 & 66063 \\
\hline 27 & $2700^{1}$ & 63116 & 67990 & 29535 \\
\hline 28 & & 69428 & 67600 & 27432 \\
\hline 29 & & 54997 & 51083 & 12728 \\
\hline 30 & & 46795 & 49736 & 177 \\
\hline 31 & & 70095 & 71074 & 25638 \\
\hline 32 & & 69675 & 74660 & 50189 \\
\hline 33 & & 33820 & 54982 & 29610 \\
\hline 34 & & $21315^{1}$ & 60107 & 3610 \\
\hline 35 & & & 58600 & 5012 \\
\hline 36 & & & 62650 & 13001 \\
\hline Average. & 57615 & 62435 & 86934 & 57908 \\
\hline
\end{tabular}

1 Nos. 5 and 6 died at the end of the twenty-seventh and thirty-fourth week, respectively. 
No. 6 ran uniformly low; its maximum run was 86895 revolutions at the seventeenth week and its minimum run for an entire week was 15404 revolutions the twelfth week. It died the thirtyfourth week. Its average weekly run was 62435 revolutions.

No. 7 was the most active of the alcohol line. It showed great activity from the eleventh to the twentieth. week. Its maximum was 142762 revolutions at the thirteenth week and its minimum, not counting the first week, was 51083 revolutions during the twenty-ninth week. Its average run per week was 86934 revolutions.

No. 8 ran its maximum of 131473 revolutions at the eleventh week. It decreased steadily and near the end of the experiment made some very small runs, of which 177 revolutions at the thirtieth week was the least. Its average weekly run was 57908 revolutions.

No. 9 showed great activity from the tenth to the twentieth week, from the twenty-fourth to the twenty-seventh week and again the thirty-second week. Its maximum run was 134027 revolutions at the eleventh week and its minimum run, not counting the first week was 67089 revolutions at the thirty-fifth week. Its average weekly run was 99693 revolutions.

No. 10 was the least active of this line; it rose gradually to its maximum run of 106697 revolutions at the fourteenth week and then decreased to its minimum run of 10253 revolutions at the twenty-ninth week, but increased somewhat later. Its average run per week was 58843 revolutions.

No. 11 shows a reversed record, for it ran low until its twentyseventh week. Its maximum run was 111132 revolutions at the thirty-fifth week and its minimum run 14947 at the thirteenth week when many of the mice were running their highest. Its average weekly run was 65006 revolutions.

No. 12 exercised the most of all the sixteen mice. It reached its maximum of 192395 revolutions at the thirteenth week and kept up its great activity throughout the experiment, not going below 100000 revolutions until the thirty-fourth week. Its minimum run was 54392 revolutions at the twelfth week. Its average run per week was 124886 revolutions. 
TABLE 4

Number of revolutions per week of the mice in the nicotine line

\begin{tabular}{|c|c|c|c|c|}
\hline $\begin{array}{c}\text { AGE OY MICE IN } \\
\text { WEEKS }\end{array}$ & $\begin{array}{l}\text { MOUSE } \\
\text { No. } 9\end{array}$ & $\begin{array}{l}\text { MOUsE } \\
\text { No. } 10\end{array}$ & $\begin{array}{l}\text { MousR } \\
\text { No. } 11\end{array}$ & $\begin{array}{l}\text { Mouss } \\
\text { No. } 12\end{array}$ \\
\hline 9 & 25227 & 36370 & 44240 & 75805 \\
\hline 10 & 112286 & 68748 & 31218 & 69467 \\
\hline 11 & 134027 & 53430 & 37226 & 122325 \\
\hline 12 & 127474 & 75451 & 19167 & 154392 \\
\hline 13 & 107162 & 98414 & 14947 & 192395 \\
\hline 14 & 119168 & 106697 & 40222 & 175052 \\
\hline 15 & 122093 & 94483 & 33564 & 145488 \\
\hline 16 & 133615 & 93275 & 29488 & 160474 \\
\hline 17 & 122570 & 80278 & 61232 & 135952 \\
\hline 18 & 123667 & 77205 & 69841 & 150792 \\
\hline 19 & 110990 & 82355 & 72800 & 169845 \\
\hline 20 & 110770 & 68310 & 64275 & 134322 \\
\hline 21 & 94691 & 74252 & 51091 & 163060 \\
\hline 22 & 91428 & 19104 & 71540 & 157709 \\
\hline 23 & 92467 & 46020 & 49708 & 152201 \\
\hline 24 & 102065 & 41973 & 62118 & 139931 \\
\hline 25 & 108910 & 66335 & 80280 & 148290 \\
\hline 26 & 106312 & 55715 & 66680 & 109654 \\
\hline 27 & 104340 & 30960 & 99900 & 134390 \\
\hline 28 & 80052 & 54510 & 100124 & 125528 \\
\hline 29 & 79221 & 10253 & 72718 & 100308 \\
\hline 30 & 83505 & 22382 & 68433 & 103102 \\
\hline 31 & 85974 & 50024 & 53315 & 100280 \\
\hline 32 & 102207 & 58168 & 110585 & 112674 \\
\hline 33 & 81638 & 51922 & 108188 & 101015 \\
\hline 34 & 78748 & 34335 & 95980 & 97185 \\
\hline 35 & 67089 & 38428 & 111132 & 90943 \\
\hline 36 & 83434 & 58214 & 100286 & 74228 \\
\hline Average... & 99693 & 58843 & 65006 & 124886 \\
\hline
\end{tabular}

No. 13 ran low during the entire experiment. Its maximum run was 79613 revolutions at the sixteenth week. Its minimum run was 14704 at the thirty-second week. Its average weekly run was 40052 revolutions.

No. 14 showed its greatest activity from the eleventh to the seventeenth week, its maximum run being 135316 revolutions at the fifteenth week. After that it decreased rapidly till its death in the thirty-second week. Its minimum run for an entire 
TABLE :

Number of revolutions per week of the mice in the caffeine line

\begin{tabular}{|c|c|c|c|c|}
\hline $\begin{array}{c}\text { AGE OF MICE IN } \\
\text { WREKS }\end{array}$ & $\begin{array}{l}\text { MOUSE } \\
\text { No. } 13\end{array}$ & $\begin{array}{l}\text { MoUsE } \\
\text { No. } 14\end{array}$ & $\begin{array}{l}\text { MOUSE } \\
\text { NO. } 15\end{array}$ & $\begin{array}{l}\text { Mousf } \\
\text { No. } 16\end{array}$ \\
\hline 9 & 27395 & 25160 & 51796 & 51991 \\
\hline 10 & 43205 & 79935 & 22685 & 79617 \\
\hline 11 & 41960 & 102615 & 33712 & 143242 \\
\hline 12 & 55474 & 121164 & 44478 & 83853 \\
\hline 13 & 34623 & 87722 & 44476 & 141494 \\
\hline 14 & 53403 & 97081 & 66508 & 149307 \\
\hline 15 & 47585 & 135316 & 64128 & 128433 \\
\hline 16 & 79613 & 110157 & 79980 & 105980 \\
\hline 17 & 48182 & 104390 & 46347 & 112592 \\
\hline 18 & 56228 & 55084 & 60028 & 88598 \\
\hline 19 & 51672 & 82158 & 58585 & 103555 \\
\hline 20 & 66583 & 65340 & 72885 & 123895 \\
\hline 21 & 53286 & 66561 & 58847 & 87510 \\
\hline 22 & 49292 & 83704 & 45256 & 92468 \\
\hline 23 & 58332 & 61774 & 48048 & 72504 \\
\hline 24 & 45728 & 61374 & 38114 & 90872 \\
\hline 25 & 35560 & 26366 & 47217 & 111157 \\
\hline 26 & 33015 & 12512 & 40410 & 74635 \\
\hline 27 & 33246 & 4230 & 43822 & 70652 \\
\hline 28 & 23602 & 12657 & 38868 & 77981 \\
\hline 29 & 24812 & 451 & 36690 & 66117 \\
\hline 30 & 18800 & 1182 & 29057 & 44623 \\
\hline 31 & 21940 & 1007 & 44248 & 54748 \\
\hline 32 & 14704 & $72^{1}$ & 51550 & 72710 \\
\hline 33 & 22393 & & 59412 & 66271 \\
\hline 34 & 26256 & & 42240 & 71520 \\
\hline 35 & 26797 & & 41616 & 77685 \\
\hline 36 & 27790 & & 45855 & 54098 \\
\hline Average. & 40052 & 47036 & 48815 & 89218 \\
\hline
\end{tabular}

${ }^{1}$ No. 14 died in the thirty-second week of the experiment.

week was 451 revolutions at the twenty-ninth week. Its average run each week was 47036 revolutions.

No. 15 ran much the same as No. 13, reaching a maximum of 79980 revolutions at the sixteenth week. Its minimum run was 22685 at the tenth week. Its average weekly run was 48815 revolutions.

No. 16 was the most active of the caffeine line. It showed great activity from the eleventh to the twentieth week and rose 
again at the twenty-fifth week. Its maximum run was 149307 revolutions at the fourteenth week, and its minimum run, 44623 revolutions at the thirtieth week. Its average weekly run was 89218 revolutions.

\section{Comparison of the weekly activity of all the mice}

Although all these mice were of the same sex, the same age and closely related, yet even in the same lines they showed great individual variations in their activity.

Some time was necessary for the mice to get accustomed to the cages. The first week's runs are low, although the animals had been in the cages almost a week before the experiment was begun. All but one of the mice showed their greatest activity in the early part of the experiment. The decline in the latter part was probably due to increase in age. Slonaker ('07, '12) found that white rats are most active in early life.

The mice may be divided into two types, with one exception. Type 1 had a period of high activity falling within the tenth to the twenty-third week, and a second period of great activity occurring between the twenty-fourth and the thirty-second week. This would seem to be normal. This group includes six mice, controls Nos. 1, 2 and 4, nicotine Nos. 9 and 12 and caffeine No. 16. These six mice were more active than any of the others. None of them died.

Type 2 exhibited only one period of high activity which fell within the tenth to the twentieth week; the runs then decreased steadily to the end of the experiment. This includes nine mice, control No. 3, all of the alcohol mice, nicotine No. 10 and caffeine Nos. 13, 14 and 15. Only one of these, alcohol No. 7, is above the average in activity; all the others fall below the average. Three of these mice died. It is evident that these mice had less vitality than those of the first type.

No. 11 of the nicotine line is an exception to these two types. Its period of high activity did not begin until the twenty-eighth week, and its maximum run came at the thirty-fifth week. 


\section{Weekly activity of the average of each line}

In order to compare the activity of the different lines the average of each line is recorded in table 6 and figure 2. Some of the mice in the alcohol and caffeine lines died during the course of the experiment. In such cases the last entire week of activity was counted in making the averages.

From table 6 and figure 2 it will be seen that the controls reached their maximum run of 119523 revolutions at the twelfth

TABLE 6

Number of revolutions per week of the average of each line

\begin{tabular}{|c|c|c|c|c|}
\hline $\begin{array}{l}\text { AGE OF MICE IN } \\
\text { WEEKS }\end{array}$ & $\begin{array}{l}\text { CONTHOL } \\
\text { MECE }\end{array}$ & $\begin{array}{l}\text { ALCOHOL } \\
\text { MTCE }\end{array}$ & $\begin{array}{l}\text { NICOTINE } \\
\text { MICE }\end{array}$ & $\begin{array}{l}\text { CAFFEINE } \\
\text { MICE }\end{array}$ \\
\hline 9 & 69656 & 43195 & 45410 & 39063 \\
\hline 10 & 99468 & 88758 & 45429 & 56110 \\
\hline 11 & 118618 & 111833 & 86752 & 80382 \\
\hline 12 & 119523 & 65648 & 69121 & 76242 \\
\hline 13 & 115634 & 85325 & 103254 & 79579 \\
\hline 14 & 113417 & 69756 & 110289 & 91575 \\
\hline 15 & 105263 & 89702 & 98907 & 93865 \\
\hline 16 & 99559 & 86467 & 108213 & 93932 \\
\hline 17 & 101728 & 90408 & 100008 & 77878 \\
\hline 18 & 99649 & 74630 & 105376 & 64984 \\
\hline 19 & 97276 & 72411 & 108997 & 73992 \\
\hline 20 & 83687 & 77078 & 94419 & 82176 \\
\hline 21 & 88639 & 66261 & 95773 & 66551 \\
\hline 22 & 81421 & 67392 & 84945 & 67680 \\
\hline 23 & 92592 & 71552 & 85099 & 60164 \\
\hline 24 & 90639 & 64822 & 86522 & 59022 \\
\hline 25 & 99303 & 74301 & 100954 & 55075 \\
\hline 26 & 67273 & 52144 & 84590 & 40143 \\
\hline 27 & 82039 & 53547 & 92397 & 37987 \\
\hline 28 & 88769 & 54820 & 90055 & 38277 \\
\hline 29 & 76405 & 39603 & 65625 & 32017 \\
\hline 30 & 66558 & 32236 & 69355 & 23415 \\
\hline 31 & 77773 & 55602 & 72398 & 30485 \\
\hline 32 & 79556 & 64841 & 95908 & 46321 \\
\hline 33 & 68672 & 39471 & 85691 & 49359 \\
\hline 34 & 59622 & 25011 & 76562 & 46672 \\
\hline 35 & 59156 & 31806 & 76898 & 48699 \\
\hline 36 & 57907 & 37825 & 79040 & 42581 \\
\hline Average. & 87493 & 63767 & 86321 & 59079 \\
\hline
\end{tabular}




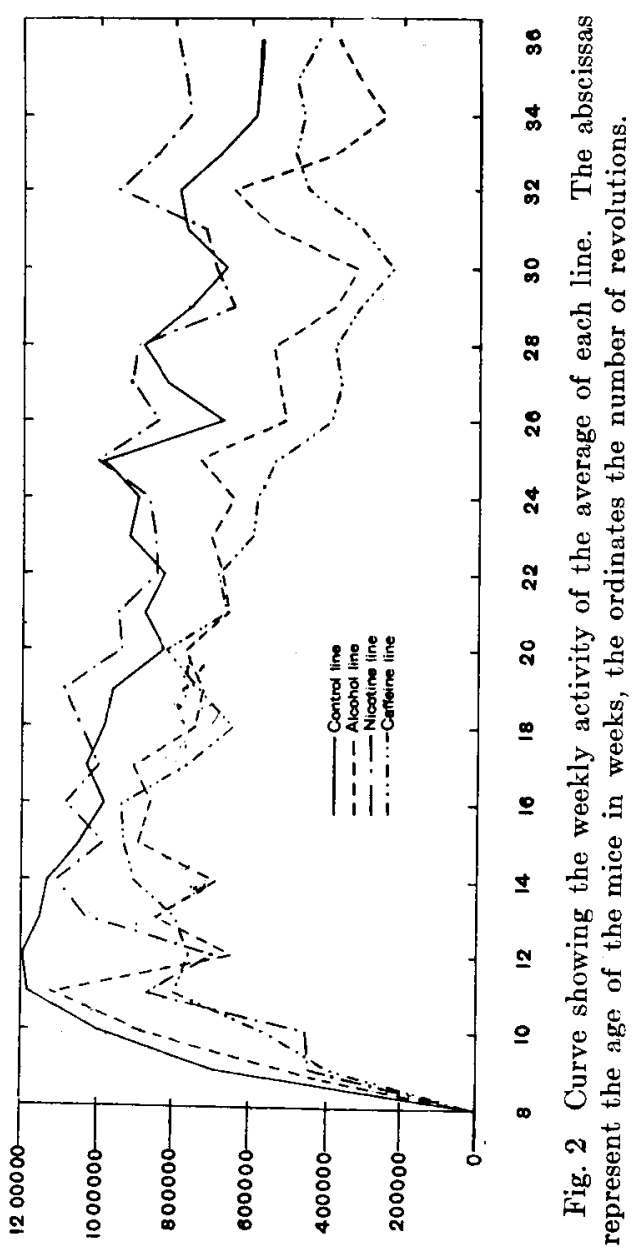


week and then showed a rather gradual decline in running to the end of the experiment. Their last run, 57907 revolutions, was their least. Their average weekly run was 87493 revolutions.

The alcohol line rose almost immediately to their maximum of 111833 revolutions at the eleventh week, but after that declined rapidly and ran low throughout the experiment. Their last run was 37825 revolutions and their minimum 25011 revolutions at the thirty-fourth week. Their average weekly run was 63767 revolutions.

The nicotine line reached their maximum of 110289 revolutions at the fourteenth week. They retained a fairly constant level with a slight decline at the end of the experiment. Their last run was 79040 revolutions and their least, if the first two weeks are left out of account, 65625 revolutions at the twenty-ninth week. Their average weekly run was 86321 revolutions.

The caffeine line rose slowly to their maximum of 93932 at the end of the sixteenth week, and showed a rather steady decline to the end of the experiment. Their last run was 42581 revolutions and their minimum run, 23415 revolutions at the thirtieth week. Their average weekly run was 59079 revolutions.

The control and nicotine lines ran close together for a large part of the experiment. The controls however reached a higher maximum and reached it sooner than the nicotine mice, but after the fifteenth week the nicotine line was generally slightly ahead of the controls. These two lines correspond to type 1 .

The alcohol and caffeine lines ran close together, except at the maximum of the former. After the thirteenth week they ran entirely below the control and nicotine mice. Most of the time the alcohol mice ran somewhat higher than the caffeine mice. These two lines correspond to type 2 .

The alcohol mice varied more than any of the other lines. The average weekly decrease from their maximum run to their final run was 3360 revolutions, that of the caffeine mice 2566 revolutions, the controls 2566 revolutions and the nicotine mice 1420. The nicotine line kept a more constant level than the others because both No. 11 and No. 12 were very active in the latter part of the experiment. 


\section{TOTAL ACTIVITY}

The total activity of each mouse is shown in tables $7,8,9$ and 10.

TABLE 7

Total work in revolutions done by the control mice

\begin{tabular}{|c|c|c|c|c|}
\hline $\begin{array}{l}\text { AGE OF MICE IN } \\
\text { WEEKB }\end{array}$ & $\begin{array}{l}\text { Mouse } \\
\text { No. } 1\end{array}$ & $\begin{array}{l}\text { MOUgE } \\
\text { No. } 2\end{array}$ & $\begin{array}{l}\text { MOVEE } \\
\text { No. } 3\end{array}$ & $\begin{array}{l}\text { Movge } \\
\text { No. } 4\end{array}$ \\
\hline 9 & 80243 & 78785 & 55718 & 63878 \\
\hline 10 & 201178 & 161313 & 126759 & 187248 \\
\hline 11. & 323297 & 279619 & 225829 & 327226 \\
\hline 12 & 455890 & 404620 & 325829 & 447721 \\
\hline 13 & 594968 & 545450 & 406836 & 549347 \\
\hline 14 & 721323 & 693026 & 505802 & 630119 \\
\hline 15 & 845280 & 824300 & 587422 & 714319 \\
\hline 16 & 940150 & 953495 & 667450 & 808464 \\
\hline 17 & 1032748 & $\begin{array}{lll}1073 & 163\end{array}$ & 752820 & 917739 \\
\hline 18 & 1141155 & 1164467 & 822404 & 1047043 \\
\hline 19 & 1228145 & 1248567 & 895504 & 1191956 \\
\hline 20 & 1294262 & 1232554 & 974248 & 1297858 \\
\hline 21 & 1368549 & 1418201 & 1032895 & 1433836 \\
\hline 22 & 1441439 & 1482482 & 1091014 & 1564231 \\
\hline 23 & 1523559 & 1568437 & 1167754 & 1689803 \\
\hline 24 & 1612013 & 1661977 & 1222299 & 1757950 \\
\hline 25 & 1719162 & 1771492 & 1276831 & 1883968 \\
\hline 26 & 1810884 & 1872707 & 1336891 & 2000063 \\
\hline 27 & 1904776 & 1947187 & 1390995 & 2105843 \\
\hline 28 & 1993531 & 2057827 & 1446175 & 2206343 \\
\hline 29 & 2060602 & 2177208 & 1487229 & 2284356 \\
\hline 30 & 2138041 & 2240573 & 1528110 & 2368903 \\
\hline 31 & 2226069 & 2322173 & 1575434 & 2463043 \\
\hline 32 & 2311414 & 2407275 & 1627598 & 2568658 \\
\hline 33 & 2384066 & 2482100 & 1663753 & 2659715 \\
\hline 34 & 2432446 & 2554553 & 1703578 & 2737545 \\
\hline 35 & 2506906 & 2613873 & 1744324 & 2799645 \\
\hline 36 & 2576101 & 2677427 & 1785571 & 2857278 \\
\hline
\end{tabular}

The total runs are $1785571,2576101,2677427$ and 2857278 revolutions. Three mice in this line showed great activity while one was much less active. No. 3 ran 62 per cent as much as No. 4, No. 1 ran 90 per cent and No. 294 per cent as much as No. 4. 
TABLE 8

Total work in revolutions done by the alcohol mice

\begin{tabular}{|c|c|c|c|c|}
\hline $\begin{array}{c}\text { AGI OF MYE IN } \\
\text { WEEKS }\end{array}$ & $\begin{array}{c}\text { MOUBE } \\
\text { NO. } 5\end{array}$ & $\begin{array}{l}\text { Mov8E } \\
\text { No. } 6\end{array}$ & $\begin{array}{l}\text { MOUBE } \\
\text { No. } 7\end{array}$ & $\begin{array}{c}\text { MOUEE } \\
\text { No.8 }\end{array}$ \\
\hline 9 & 57634 & 41370 & 28430 & 25345 \\
\hline 10 & 132549 & 123064 & 104660 & 167538 \\
\hline 11 & 257850 & 181508 & 226773 & 299011 \\
\hline 12 & 314392 & 196912 & 333453 & 392976 \\
\hline 13 & 419137 & 228605 & 476415 & 454877 \\
\hline 14 & 453517 & 261127 & 604910 & 538506 \\
\hline 15 & 533609 & 324255 & 734303 & 624702 \\
\hline 16 & 603331 & 403513 & 847863 & 708029 \\
\hline 17 & 677405 & 490308 & 964868 & 791687 \\
\hline 18 & 734374 & 559924 & 1064006 & 864485 \\
\hline 19 & 787204 & 631128 & 1160931 & 933169 \\
\hline 20 & 844291 & 688446 & 1273178 & 1014831 \\
\hline 21 & 896076 & 742873 & 1370271 & 1076569 \\
\hline 22 & 943373 & 806296 & 1459466 & 1146224 \\
\hline 23 & 989001 & 872798 & 1556301 & 1223469 \\
\hline 24 & 1032681 & 944308 & 1633034 & 1290833 \\
\hline 25 & 1089512 & 1019876 & 1730244 & 1358438 \\
\hline 26 & 1091976 & 1073906 & 1815664 & 1424501 \\
\hline 27 & $1094676^{1}$ & 1137022 & 1883654 & 1454036 \\
\hline 28 & & 1206520 & 1951254 & 1481468 \\
\hline 29 & & 1261517 & 2002337 & 1494196 \\
\hline 30 & & 1308312 & 2052073 & 1494373 \\
\hline 31 & & 1378407 & 2123147 & 1520011 \\
\hline 32 & & 1448082 & 2197807 & 1570200 \\
\hline 33 & & 1. 481902 & 2252789 & 1599810 \\
\hline 34 & & $1503217^{1}$ & 2312896 & 1603420 \\
\hline 35 & & & 2371496 & 1608432 \\
\hline 36 & & & 2434146 & 1621433 \\
\hline
\end{tabular}

${ }^{1}$ No. 5 and No. 6 died at the end of the twenty-seventh and thirty-fourth week respectively.

No. 5 had run 1094676 revolutions at its twenty-seventh week, No. 61503217 at its thirty-fourth week, and Nos. 8 and 7, 1621433 and 2434146 respectively at the end of the experiment. The record of No. 5 was 58 per cent of No. 7 at the twentyseventh week, No. 665 per cent of No. 7 at the thirty-fourth week and No. 866 per cent at the end of the experiment. Three of this line showed little activity, while one was much more active. 
TABLE 9

Total work in revolutions done by the nicotine mice

\begin{tabular}{|c|c|c|c|c|}
\hline $\begin{array}{l}\text { AGE OF MICH IN } \\
\text { WEEES }\end{array}$ & $\begin{array}{l}\text { MOtrE } \\
\text { No. } 9\end{array}$ & $\begin{array}{l}\text { MOU\&E } \\
\text { No. } 10\end{array}$ & $\begin{array}{l}\text { Mouse } \\
\text { No. } 11\end{array}$ & $\begin{array}{l}\text { Mov8E } \\
\text { No. } 12\end{array}$ \\
\hline 9 & 25227 & 36370 & 44240 & 75805 \\
\hline 10 & 137513 & 105118 & 75458 & 145272 \\
\hline 11 & 271540 & 158548 & 112684 & 267597 \\
\hline 12 & 399014 & 233999 & 131751 & 321989 \\
\hline 13 & 506176 & 332413 & 146698 & 514384 \\
\hline 14 & 625344 & 439110 & 186910 & 689436 \\
\hline 15 & 747437 & 533595 & 220474 & 834924 \\
\hline 16 & 881052 & 626870 & 249962 & 995398 \\
\hline 17 & 1003622 & 707148 & 311194 & 1131350 \\
\hline 18 & 1127289 & 784353 & 381035 & 1282142 \\
\hline 19 & 1238279 & 866708 & 453835 & 1451987 \\
\hline 20 & 1349049 & 935018 & 518110 & 1587309 \\
\hline 21 & 1443740 & 1009270 & 569201 & 1749369 \\
\hline 22 & 1535168 & 1028374 & 640741 & 1907078 \\
\hline 23 & 1627635 & 1074394 & 690449 & 2059210 \\
\hline 24 & 1729700 & 1116367 & 752567 & 2199210 \\
\hline 25 & 1838610 & 1182702 & 832847 & 2347500 \\
\hline 26 & 1944922 & 1258417 & 899527 & 2457154 \\
\hline 27 & 2049262 & 1269375 & 999427 & 2591544 \\
\hline 28 & 2129320 & 1323887 & 1099551 & 2717072 \\
\hline 29 & 2208541 & 1334140 & 1172269 & 2817380 \\
\hline 30 & 2292046 & 1356522 & 1240702 & 2920482 \\
\hline 31 & 2378020 & 1406546 & 1294017 & 3020762 \\
\hline 32 & 2480227 & 1464714 & 1404602 & 3133436 \\
\hline 33 & 2561865 & 1516636 & 1512790 & 3234451 \\
\hline 34 & 2640613 & 1550971 & 1608770 & 3331636 \\
\hline 35 & 2707702 & 1589399 & 1719902 & 3422579 \\
\hline 36 & 2791136 & 1647613 & 1820188 & 3496807 \\
\hline
\end{tabular}

The mice in the nicotine line ran $1647613,1820188,2791136$ and 3496807 revolutions during the experiment. One showed very great activity, another great activity while two were rather inactive. No. 10 ran 47 per cent as much as No. 12, No. 11 ran 52 per cent and No. 980 per cent as much as No. 12. 
TABLE 10

Total work in revolutions done by the caffeine mice

\begin{tabular}{|c|c|c|c|c|}
\hline $\begin{array}{l}\text { AGD OF MICE IN } \\
\text { WEEKSS }\end{array}$ & $\begin{array}{l}\text { Mouse } \\
\text { No. } 13\end{array}$ & $\begin{array}{l}\text { Morse } \\
\text { No. } 14\end{array}$ & $\begin{array}{l}\text { MOJBE } \\
\text { No.15 }\end{array}$ & $\begin{array}{l}\text { MOUSE } \\
\text { No. } 16\end{array}$ \\
\hline 9 & 27395 & 25160 & 51796 & 51991 \\
\hline 10 & 70600 & 104095 & 74481 & 131608 \\
\hline 11 & 112560 & 206710 & 108193 & 274850 \\
\hline 12 & 168034 & 327874 & 152671 & 358703 \\
\hline 13 & 202657 & 415596 & 207147 & 500197 \\
\hline 14 & 256060 & 512677 & 273655 & 649504 \\
\hline 15 & 303645 & 547993 & 337783 & 771937 \\
\hline 16 & 383258 & 658150 & 417763 & 883917 \\
\hline 17 & 431440 & 762540 & 464110 & 996509 \\
\hline 18 & 487668 & 837624 & 524138 & 1085107 \\
\hline 19 & 539340 & 919782 & 582722 & 1188662 \\
\hline 20 & 605923 & 985122 & 655608 & 1312557 \\
\hline 21 & 659209 & 1051683 & 714455 & 1400067 \\
\hline 22 & 708501 & 1135387 & 759711 & 1492535 \\
\hline 23 & 766833 & 1197161 & 807759 & 1565039 \\
\hline 24 & 812561 & 1258535 & 845873 & 1655911 \\
\hline 25 & 848121 & 1284901 & 893080 & 1766068 \\
\hline 26 & 881936 & 1297413 & 933490 & 1841703 \\
\hline 27 & 914382 & 1301643 & 977312 & 1912355 \\
\hline 28 & 937984 & 1314300 & 1016170 & 1990336 \\
\hline 29 & 962796 & 1314751 & 1052860 & 2056453 \\
\hline 30 & 981596 & 1315933 & 1081917 & 2101076 \\
\hline 31 & 1003536 & 1316940 & 1126165 & 2155824 \\
\hline 32 & 1018240 & $1317012^{1}$ & 1177715 & 2228534 \\
\hline 33 & 1040633 & & 1237125 & 2294805 \\
\hline 34 & 1066889 & & 1279367 & 2366325 \\
\hline 35 & 1093686 & & 1320983 & 2444010 \\
\hline 36 & 1121476 & & 1366838 & 2498108 \\
\hline
\end{tabular}

1 No. 14 died at the end of the thirty-second week.

One mouse in the caffeine line showed great activity and three were much less active. Nos. 13, 15 and 16 ran 1121476,1366838 and 2498108 revolutions during the course of the experiment. No. 14 ran 1317612 revolutions to its thirtysecond week when it died. No. 13's record was 49 per cent of No. 16. No. 15 was 55 .per cent and No. 14 was 60 per cent of No. 16 at the thirty-second week. 


\section{COMPARISON OF THE TOTAL ACTIVITY OF ALI, THE MICE}

\section{TABLE 11}

In the following table the mice are arranged in the order of their tolal activity. Total activity of all the mice in revolutions and in miles

\begin{tabular}{|c|c|c|c|}
\hline & MOTSE NO. & NUMBER ÓF REVOLUTIONS & MILES RUN \\
\hline Caffeine. & 13 & 1121476 & 556.06 \\
\hline Caffeine. & 15 & 1366838 & 677.72 \\
\hline Alcohol'... & 5 & 1094676 (at 27 weeks) & 542.77 (at 27 weeks) \\
\hline Caffeine'. & 14 & 1317012 (at 32 weeks) & 653.01 (at 32 weeks) \\
\hline Alcohol ${ }^{1}$. . & 6 & 1503217 (at 34 weeks) & 745.35 (at 34 weeks) \\
\hline Alcohol. . & 8 & 1621433 & 803.96 \\
\hline Nicotine. & 10 & 1647613 & 816.94 \\
\hline Control... & 3 & 1785571 & 885.34 \\
\hline Nicotine. . & 11 & 1820188 & 898.72 \\
\hline Alcohol... & 7 & 2434146 & 1206.92 \\
\hline Caffeine. . & 16 & 2498108 & 1238.65 \\
\hline Control. . & 1 & 2576101 & 1277.31 \\
\hline Control... & 2 & 2677427 & 1327.56 \\
\hline Nicotine. . & 9 & 2791136 & 1383.94 \\
\hline Control. & 4 & 2857278 & 1416.73 \\
\hline Nicotine... & 12 & 3496807 & 1733.83 \\
\hline Average. . & & 2076622 & 1010.30 \\
\hline
\end{tabular}

${ }^{1}$ Nos. 5,14 and 6 died at the twenty-seventh, thirty-second and thirty-fourth weeks respectively.

From table 11 it will be seen that below the average in activity are 3 caffeine mice, 3 alcohol mice, 2 nicotine mice and one control. Above the average are 1 caffeine mouse, 1 alcohol mouse, 2 nicotine mice and 3 controls. Caffeine No. 13 was the least active of all the mice. Nicotine No. 12 was the most active. No. 13 exercised only 32 per cent as much as No. 12 . No. 13 is 54 per cent and No. 12 is 169 per cent of the average.

When the revolutions are reduced to miles the average daily run of all the mice is 4.93 miles. The average daily run of the mouse that ran the least is 2.84 miles, and of the mouse that ran the most 8.99 miles. The greatest run in one day of any mouse is 16.8 miles. 
Total activity of the average of each line

TABLE 12

Total work in revolutions of the average of each line

\begin{tabular}{|c|c|c|c|c|}
\hline $\begin{array}{c}\text { AGE OF MITCE IN } \\
\text { WEEKE }\end{array}$ & CONTROL & ALCOHOL & NICOTINE & CAFFEINE \\
\hline 9 & 69656 & 43195 & 45410 & 39063 \\
\hline 10 & 169124 & 131953 & 90839 & 95173 \\
\hline 11 & 287742 & 243786 & 177591 & 175555 \\
\hline 12 & 407265 & 309434 & 246712 & 251797 \\
\hline 13 & 522899 & 394759 & 349966 & 331376 \\
\hline 14 & 636316 & 464515 & 460255 & 422951 \\
\hline 15 & 741579 & 554217 & 559162 & 516816 \\
\hline 16 & 841138 & 640684 & 667375 & 610748 \\
\hline 17 & 942866 & 731092 & 767383 & 688626 \\
\hline 18 & 1042515 & 805722 & 872759 & 753610 \\
\hline 19 & 1139791 & 878133 & 981756 & 827602 \\
\hline 20 & 1223478 & 955211 & 1076175 & 909778 \\
\hline 21 & 1312117 & 1021472 & 1171948 & 976329 \\
\hline 22 & 1393538 & 1088864 & 1256893 & 1044009 \\
\hline 23 & 1486130 & 1160416 & 1341992 & 1104173 \\
\hline 24 & 1576769 & 1225238 & 1427514 & 1163195 \\
\hline 25 & 1676072 & 1299539 & 1528468 & 1218270 \\
\hline 26 & 1743345 & 1351683 & 1613058 & 1258413 \\
\hline 27 & 1825384 & 1405210 & 1705455 & 1296400 \\
\hline 28 & 1914153 & 1460030 & 1795510 & 1334677 \\
\hline 29 & 1990558 & 1499633 & 1861135 & 1366694 \\
\hline 30 & 2057116 & 1531869 & 1930490 & 1390109 \\
\hline 31 & 2134889 & 1587471 & 2002888 & 1420594 \\
\hline 32 & 2214445 & 1652362 & 2098796 & 1466915 \\
\hline 33 & 2273117 & 1691833 & 2184487 & 1516274 \\
\hline 34 & 2332739 & 1716844 & 2261049 & 1562946 \\
\hline 35 & 2391895 & 1747650 & 2337947 & 1611645 \\
\hline 36 & 2449802 & 1785475 & 2416987 & 1654226 \\
\hline
\end{tabular}

In table 12 and figure 3 the total activity of each line is averaged. The average total activity of the caffeine line was 1654226 revolutions, of the alcohol line 1785475 revolutions, of the nicotine line 2416987 revolutions and of the control line 2449802 revolutions. The caffeine average is 68 per cent of the control average, the alcohol average is 73 per cent and the nicotine average is 99 per cent of the control average. 


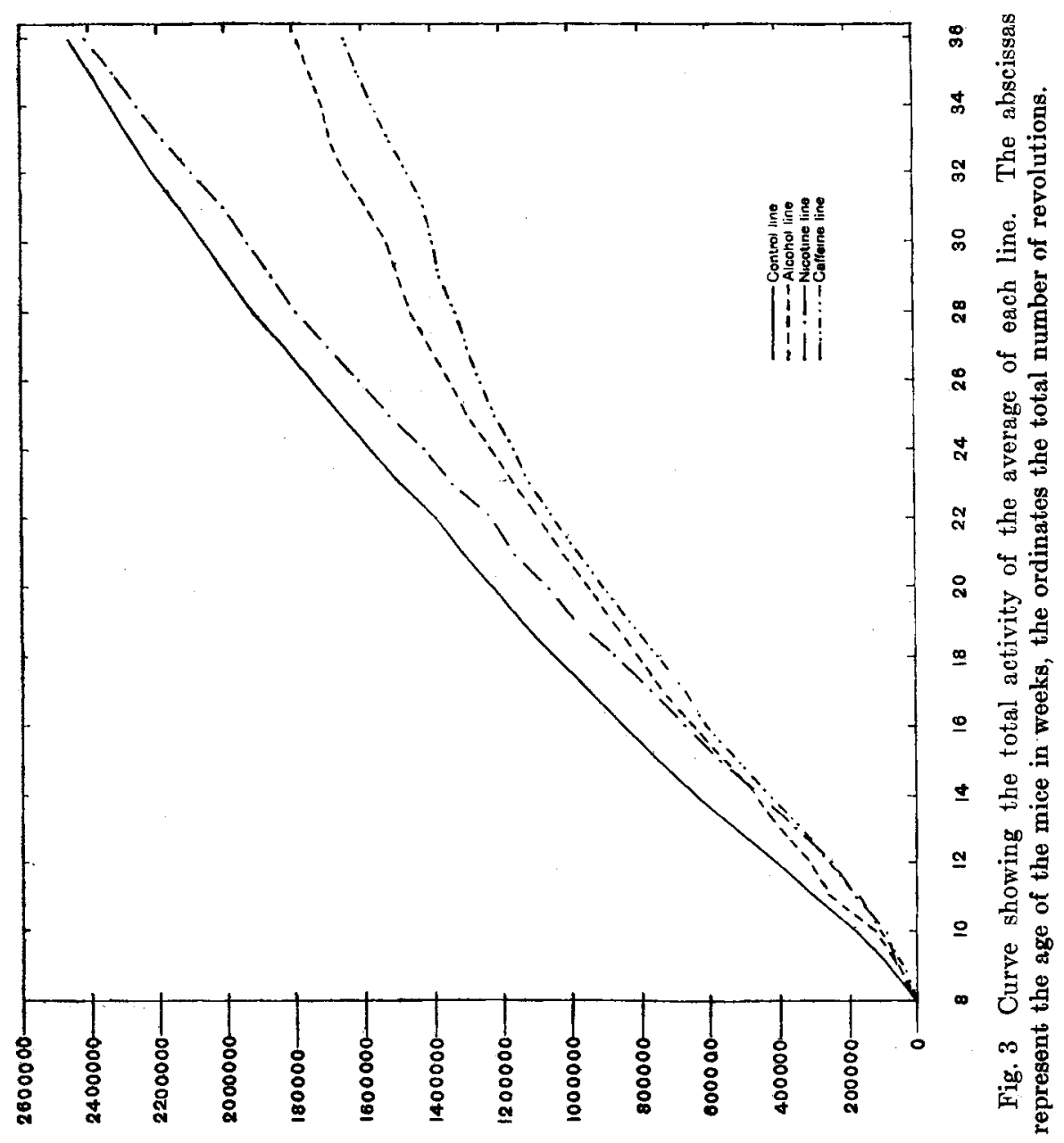


From figure 3 it will be seen that the control line leads throughout the entire time. The nicotine line excels the caffeine line at the sixth week and the alcohol line after the ninth week, and then gradually increases, keeping about an even distance from the control line, until the last two months when it more nearly approaches the control line. The alcohol average excels the nicotine line for eight weeks, but after that rises much more slowly. The caffeine average equals the nicotine average for five weeks, but after that is the lowest of all.

\section{DISCUSSION OF THE EFFECTS OF ALCOHOL, NICOTINE AND CAFFEINE ON THE ACTIVITY OF WHITE MICE}

\section{Control line}

The control mice have the highest total activity of all the lines. They also have the highest average maximum. Three of them, Nos. 1, 2 and 4, belong to type 1, having a second period of high activity. These three are well above the average in total activity. No. 3 is less active, coming below the average. It belongs to type 2 . It weighed 35 grams while the other control mice weighed 24, 24 and 25 grams respectively. Only one other mouse, caffeine No. 16, weighed as much as 30 grams. There may be some correlation between the inactivity of control No. 3 and its weight. None of the controls died. They gained on an average 7.5 grams throughout the experiment.

\section{Alcohol line}

Of the mice subjected to alcohol three are decidedly below the average in total activity, while one is slightly above it. They all belong to type 2, none having a second period of high activity, as the six most vigorous mice did. Three of them, Nos. 5, 7 and 8, start out well, but all except No. 7 rapidly decrease in activity. No. 7 seems to be an average mouse of type 2; however it loses 20 per cent of its weight during the last month. No. 5 has a maximum of 125301 revolutions but decreases very rapidly until its death when twenty-seven weeks old. No. 6 runs low all its life, its maximum being only 86895 revolutions. It died 
when thirty-four weeks old. No 8 drops from its maximum of 131473 regularly until the twenty-seventh week; after that its runs are irregular and some are very small. At the same time, from the twenty-eighth week to the end of the experiment it loses 30 per cent in weight. This great loss of weight and its small irregular run indicate that it would have died soon.

This line of mice started out well. They reached a high average maximum of 111833 revolutions during the eleventh week. This is much higher than the nicotine or caffeine line at the same time but a little lower than the maximum of the control line. In fact the nicotine line never reaches quite as high an average maximum, and the caffeine maximum is only 93932 revolutions. But after that the alcohol line drops abruptly and only once exceeds 90000 revolutions. Their total activity is 73 per cent of that of the controls.

The alcohol mice gained 6 grams each up to the twenty-fourth week, which is more than the control mice had gained during the same time. After this, however, they lost 4.5 grams on an average. None of the other lines lost any in weight except the nicotine mice.

The activity of all the mice in the alcohol line seems to have been checked and lessened. The viability of all the mice was weakened, for two died, one was evidently going to die soon and the fourth lost 20 per cent in weight. This loss in weight occurred during the last month of the experiment. The decreased activity began to show after the mice were twelve weeks old, but the loss of weight and lessened viability did not manifest themselves until after the mice were twenty-five weeks old. Thus it appears that alcohol had a markedly injurious effect on the viability an activity of these mice and that these effects were cumulative.

\section{Nicotine line}

The mice in the nicotine line show more variations than the mice in any of the other lines. No. 10 is the least active and belongs to type 2 . No. 11 is below the average in total activity. It has a very unusual record, running its least at the twelfth week 
when other mice are running their highest and reaching its maximum at the thirty-fifth week when the activity of all the other mice is decreasing. No. 9 and No. 12 belong to type 1 and both exhibit great activity. No. 12 has a remarkably high record, much higher than any of the other mice in the different lines of the experiment. It exercised 169 per cent as much as the average and 122 per cent as much as control No. 4 , the second most active of all the mice.

The average total activity of these mice is almost equal to that of the controls.

None of these mice died. They gained 3.5 grams during the experiment, which was less than half what the control mice gained. The last month they showed an average loss of 1.5 grams.

Nicotine did not seem to affect the health of these mice but may have slightly checked their growth.

Whether the wide variations in the activity of these mice were caused by nicotine cannot be known without further experiments. Nicotine may have had a stimulating effect on activity, shown particularly in No. 12 with its remarkable record and in No. 9 . No. 10 would be an exception to such a theory. No. 11 might be explained as being naturally a very inactive mouse but that the cumulative effects of nicotine stimulated him to activity. Or it is possible that all these variations were due to chance.

\section{Caffeine line}

Three of the mice in this line have low records of total activity. Nos. 13 and 15 run very low throughout the experiment. They have the lowest records of total activity of all the mice used in the experiment. No. 13 ran 54 per cent as much as the average and 39 per cent as much as No. 4, the most active mouse in the control line. No. 14 starts out well but soon decreases in activity and dies when thirty-two weeks old. These three mice belong to type 2 . No. 16 belongs to type 1 and is above the average in total activity.

The average activity of these mice is the lowest of all the lines. Their average maximum weekly run is only 93932 revolutions 
and their minimum weekly run is 24415 . Their average total activity is 68 per cent of the controls.

The caffeine mice, with the exception of No. 14, gained 11.6 grams each, whioh was more than any other line gained. But as they started out the smallest of all the mice and at the end of the experiments equalled the controls in weight, they apparently grew normally. No. 14 gained 3.5 grams and lost it again before its death.

The growth of three of these mice does not seem to have been affected by caffeine. One, however, seems to have been injured, for it died when thirty-two weeks old.

Caffeine appears to have decidedly lessened the activity of the mice.

\section{SUMMARY}

1. The control mice gained 7 grams on an average during the experiment. None of them died. Three were above the average in activity. Their total activity was greater than any other line.

2. The alcohol mice gained 6 grams on an average up to the twenty-fourth week, but lost 4.5 grams later. Two died and one probably would have died soon. Three were below the average in activity. Their total activity was 73 per cent of that of the controls. Alcohol appears to have had a markedly injurious effect on the viability and activity of these mice.

3. The mice subjected to nicotine gained 2 grams each on an average. None died. Two were below the average in activity and two above, one being far more active than any other mouse in any of the lines. Their total activity was 99 per cent of the controls.

Nicotine apparently did not injure the health of the mice, but seems to have checked their growth.

Nicotine may have had a stimulating effect on the activity of three of the mice. Or it is possible that the variations shown in this line were due to chance.

4. Three of the mice subjected to caffeine gained 11.6 grams each on an average, but since they started out the smallest of all 
the mice and at the end of the experiment equalled the controls in weight it appears that they grew normally. One mouse died.

These mice were the least active of all the lines, their total activity being 68 per cent of that of the controls. Three wte below the average in activity and one was above.

Caffeine seems to have had no influence on the growth of three of the mice, but apparently had an injurious effect on one mouse, resulting in its death.

Caffeine seems to have greatly lessened the activity of these mice.

\section{BIBLIOGRAPHY}

Aschaffenberg, Gustav 1896 Praktische Arbeit unter Alkoholwirkung. Kraepelin's Psychologische Arbeiten, Bd. 1. S. 608-626. Leipzig.

Fert, Ch. 1904 Travail et plaisir. p. 316. Paris.

Frey. 1896 Ueber den Einfluss des Alkohols auf die Muskelermüdung. Mitth. aus Klinken u. med. Instituten der Schweiz. Reihe 4, Heft 1. Basel u. Leipzig.

Harley, V. 1894. The value of sugar and the effect of smoking on muscular work. Journ. Physiol., vol. 16. pp. 97-122.

Hellsten, A. F. 1904 Ueber den Einfluss von Aklohol, Zucker und Thee auf die Leistungsfähigkeit des Muskels. Skand. Arch. f. Physiol., Bd. 16., S. $139-221$.

Hoch, A., ANd Kraepelin, E. 1896 Ueber die Wirkung der Theebestandtheile auf körperliche und geistige Arbeit. Kraepelin's Psychologische Arbeiten, Bd. 1, S. 378-488.

Hodge, C. F. 1903 The influence of alcohol on growth and development. In Physiological aspects of the liquor problem. 1 Ed. by J. S. Billings. Houghton-Mifflin, New York, pp. 359-375. 396 pp.

Kraepelin, E. 1899 Neure Untersuchungen über die psychischen Wirkungen des Alkohols. Münch., med. Wochenschrift. Jg. 46., S. 1365-1369.

Kосн, W. 1894 Inaug. Diss. Marburg.

LOMBARD, W. P. 1892 Some of the influences which affect the power of voluntary muscular contractions. Journ. Physiol., vol. 13. pp. 1-58.

Mosso, U. 1893 Action des principes actifs de la noix de kola sur la contraction musculaire. Arch. ital. de Biol. t. 19., pp. 241-256.

NICE, L. B. 1912 Comparative studies on the effects of alcohol, nicotine, tobacco smoke and caffeine on white mice. I. Effects on reproduction and growth. Jour. Exp. Zoöl., vol. 12, no. 1, pp. 133-152. 
RIvers, W. H. 1908 The influence of alcohol and other drugs on fatigue. Arnold, London, $136 \mathrm{pp}$.

Rossi, C. 1894 Ricerche sperimentale sulla fatica dei muscoli umani sotto l'azione dei veleni nervosi. Rivista sper. di F'reniatria, vol. 20, pp. 442-480.

Schomborg. 1899 Ueber die Bedeutung von Kola, Kaffee, Thee, Maté und Alkohol für die Leistung der Muskeln. Arch. f. Anat. u. Physiol. Abth., Suppl. Bd. S. 289-313.

StewART, C. C. 1898 Variations in daily activity produced by alcohol and by changes in barometric pressure and diet, with a description of recording methods. Am. Jour. Phys., vol. 1, pp. 40-56.

Slonaker, J. R: 1907 The normal activity of the white rat at different ages. Jour. Comp. Neur., vol. 17, pp. 342-359.

1908 Description of an apparatus for recording the activity of small mammals. Anat. Rec., vol. 2, no. 3, pp. 116-123.

1912a The normal activity of the white rat from birth to natural death its rate of growth and the duration of life. Journ. Animal Behav., vol. 2 , no. 1, pp. 20-42.

$1912 \mathrm{~b}$ The effect of a strictly vegetable diet on the spontaneous activity, the rate of growth, and the longevity of the albino rat. Leland Stanford Junior Univ. Pub., Stanford Univ., Cal., 36 p.

ScrNYDer, L. 1903 Alkohol und Muskelkraft. Arch. f. d. ges. Physiologie, Bd. 93, S. 451-484. 